\title{
Relationships between internal and external information systems integration, cost and quality performance, and firm profitability
}

\author{
Adam S. Maiga ${ }^{\mathrm{a}}$, Anders Nilsson ${ }^{\mathrm{b}, *}$, Christian $\mathrm{Ax}^{\mathrm{c}}$ \\ ${ }^{a}$ Columbus State University, Columbus, GA, USA \\ ${ }^{\mathrm{b}}$ Department of Business Administration, Technology and Social Sciences, Luleå University of Technology, Luleå, Sweden \\ ' School of Business, Economics and Law, University of Gothenburg, Gothenburg, Sweden
}

\section{A R T I C L E I N F O}

Article history:

Received 15 May 2014

Accepted 28 August 2015

Available online 5 September 2015

Keywords:

Information systems integration

Quality performance

Cost performance

Firm profitability

\begin{abstract}
A B S T R A C T
This paper proposes that the impact of information systems (IS) integration on manufacturing firm profitability is underestimated as a result of inadequate attention to indirect effects. The study uses structural equation modeling to investigate the associations among internal and external information system integration, quality and cost performance, and firm profitability. Overall, the results from a mail survey of 263 member firms of the Institute for Supply Management support the theoretical model. Results indicate that (a) internal IS integration has a significant positive association with external IS integration, (b) both internal IS integration and external IS integration are significantly positively associated with cost and quality performance, (c) quality performance is significantly positively associated with cost performance, and (d) both quality and cost performance have significant positive associations with firm profitability. However, the direct effects of internal and external IS integration on firm profitability are not significant. Rather, the association is through cost and quality performance, suggesting that both cost and quality performance act as intervening variables. This study extends the literature on IS integration by providing insights into a set of interrelationships that matters for the attainment of firm profitability from IS integration.
\end{abstract}

(c) 2015 Elsevier B.V. All rights reserved.

\section{Introduction}

Increasingly, information technology is used to facilitate internal coordination within a firm, enhance external integration with external constituencies (e.g., customers, suppliers), and enhance decision making among supply chain members (Li et al., 2005). In practice, the widespread nature of this phenomenon is evidenced by the increased use of information systems (IS) for integration purposes, including information systems infrastructure (e.g., data communication tools, network connection, standard data structure, unified coding standards), information systems software (e.g., enterprise-wide information systems such as SAP), and information systems applications (e.g., centralized database management systems, electronic data interchange (EDI), web-based or internetbased information systems) (Kumar, 2014).

Parallel to the increased IS integration, the research on its link to firm profitability has been the subject of considerable and enduring interest among IS researchers and practitioners. Prior studies

\footnotetext{
* Corresponding author.

E-mail addresses: maiga_adam@columbusstate.edu (A.S. Maiga), l.e.anders.nilsson@ltu.se (A. Nilsson), christian.ax@handels.gu.se (C. Ax).
}

suggest that organizations should realize greater profitability as IT resources are increasingly integrated (Weiner et al., 2004; Simoens and Scott, 2005). However, the limited number of empirical studies that has attempted to test the relationship between IS integration, such as enterprise resource planning (ERP), and firm profitability has demonstrated the complex nature of this relationship. For example, Bharadwaj (2000) compares the performance of firms that were recognized by InformationWeek magazine as information technology (IT) leaders in their industry to the performance of firms not having such recognition. Her analysis suggests that firms with high IT capabilities outperform other firms. However, subsequent analysis by Santhanam and Hartono (2003) that controls for prior financial performance finds no association between many IT capability and performance measures. Hayes et al. (2001) find that capital markets place value on ERP implementations, but Poston and Grabski (2001) find that ERP implementations have no effect on firm performance. Davenport (1998) examines companies such as FoxMeyerDrug, Mobile Europe, and Dell Computer that face financial problems with the implementation of their integrated information systems. Also, the conclusions from case studies cannot be generalized to other situations (Rackoff et al., 1985; Clemons, 1986; Banker and Kauffman, 1988; Benjamin et al., 1988; Clemons and 
Row, 1988; Clemons and Weber, 1990; Bergeron and Raymond, 1992).

However, much of the prior empirical research has sought to examine the direct effect that IS may have on firm profitability. Some researchers argue that it is not IS itself that contributes to the bottom line of a firm (e.g., Kim and Lee, 2010). This argument suggests that the influence of IS on firm profitability works through certain organizational structures (Bharadwaj, 2000), supply chain capabilities (Wu et al., 2006), interfirm collaborations (Sriram and Stump, 2004), management control systems (Kallunki et al., 2011), or other intermediate business activities (Barua et al., 1995).

To help clarify the impact of IS integration on firm profitability, we first follow Fayard et al. (2012), Bergeron and Raymond (1992), and Ward and Zhou (2006) by categorizing IS integration into two distinct, but closely related, capabilities: internal IS integration and external IS integration. Internal IS integration refers to a firm's electronic links in information technology applications to data acquisition and storage systems that facilitate the sharing of accurate and timely information in support of cross-functional processes (Hammer, 2001). External IS integration is the degree to which a firm's IT is compatible with that of other firms, such as customers and suppliers (Barua et al., 2004; Bharadwaj, 2000; Ward and Zhou, 2006; Zhou and Benton, 2007). We draw on the operations management, information systems, management accounting, and marketing literature to assess whether internal and external IS integration has a significant direct impact on firm profitability or whether firm operational performance measures act as intervening variables in the relationship between IS integration and firm profitability.

Responding to competitive pressure, organizations are competing progressively more on a variety of product dimensions (Stenzel and Stenzel, 2004). Quality and cost performance have become qualifying dimensions for competing in the marketplace (Drury, 2000). Quality performance refers to internal quality. The concept captures a manufacturing firm's ability to produce products conforming to their designed quality at an economical production cost (Crosby, 1996); thus, our quality performance measures subsume internal failure costs (Dawson and Patrickson, 1991; Ahire, 1996). Cost performance is defined as the performance of firm product cost as a function of direct labor, direct materials, and allocated overhead, plus performance in nonmanufacturing costs. Consequently, most firms have a reasonably accurate understanding of their incurred costs (D'Souza and Williams, 2000). Firm profitability includes conventional indicators of financial performance. This measure usually shows the firm's profit-making capability.

To address the research issue, we survey data from a crosssection of U.S. manufacturing firms and use structural equation modeling (SEM) to assess (a) the relations between internal IS integration and external IS integration and their impacts on quality and cost performance and (b) the relations between quality performance and cost performance and their association with firm profitability. Furthermore, this study investigates whether internal and external IS integration produces a direct effect on firm profitability or whether this relationship is established through quality and cost performance.

This paper adds to our understanding of the mediating effects of quality and cost performance on the relationship between IS integration and firm profitability in a manufacturing context. It is important for theory development concerning the association between IS integration and firm profitability to examine intervening variables that affect this relationship. Finally, an important contribution of this study is that managers, too, require a better understanding of the conditions under which IS integration should be expected to pay off. To our knowledge, no prior study has empirically tested the IS integration-firm profitability link by considering quality and cost performance.

This paper is organized as follows. The next section provides definitions of the variables used in the study. This is followed by the literature review and hypotheses development. Next, the research design and methods are presented. Finally, the results are presented, followed by a concluding discussion.

\section{Literature review and hypotheses development}

The resource-based view (RBV) of firms focuses on how organizations derive value through the strategic application of their resources (Barney, 1991; Amit and Schoemaker, 1993; Peteraf, 1993; Wade and Hulland, 2004; Holweg and Pil, 2008). A central tenet is that organizations create competitive advantages through the strategic deployment of their resources (Das and Teng, 2000). According to the RBV of firms, superior performance essentially stems from the firm's ownership or control of difficult-to-imitate resource combinations.

Despite the significance of RBV, researchers agree that it does not adequately explain how and why certain firms have a competitive advantage in situations of rapid and unpredictable change (Chan et al., 2004; Eisenhardt and Martin, 2000; Pavlou, 2004). In these situations, a sustained competitive advantage is seen as an unlikely result of just selecting the right combination of resources. To address this issue, recent studies on RBV have extended it to address dynamic resources (Wade and Hulland, 2004) and dynamic capabilities (Pavlou, 2004). In other words, although dynamic capabilities theory is derived from RBV, it differs from RBV in that it focuses on resource reconfiguration and renewal, while RBV stresses selection of resources.

This study adopts the dynamic capabilities theory and conceptualizes the construct of dynamic IS capability to address the sustainability issue of IS integration (Xiao, 2008). Capabilities are dynamic because the firm must continually build, adapt, and reconfigure internal and external competences to achieve congruence with the changing business environment when the rate of technological change is rapid, time-to-market is critical, and the nature of future competition and markets is difficult to determine (Teece et al., 1997). Dynamic capabilities create resource configurations that generate value-creating strategies (Eisenhardt and Martin, 2000).

The above arguments imply that a firm's IS integration capabilities can play a powerful enabling role in integrating and coordinating information and various activities within a functional area, across functional areas, and across the firm's boundaries of the extended value chain (Wilkin and Chenhall, 2010). This integration ability helps in timely sharing of critical information so that crucial decisions can be made (Davenport, 2000; Davenport et al., 2004; Stratman and Roth, 2002). The information advantage achieved through the adoption of sophisticated technologies and the synergistic benefits achieved through an integrated system provide the sources of sustained competitive advantage for a firm (Bharadwaj, 2000; Menor et al., 2001; Roth and Menor, 2003; Sinkovics and Roath, 2004; Swafford et al., 2008). More specifically, we argue that IS integration can equip a firm to respond to various challenges quickly and help the firm enhance its cost and quality performance, which in turn affects firm profitability.

We develop the theoretical model presented in Fig. 1. The individual relationships are discussed and hypothesized in the following sections. 


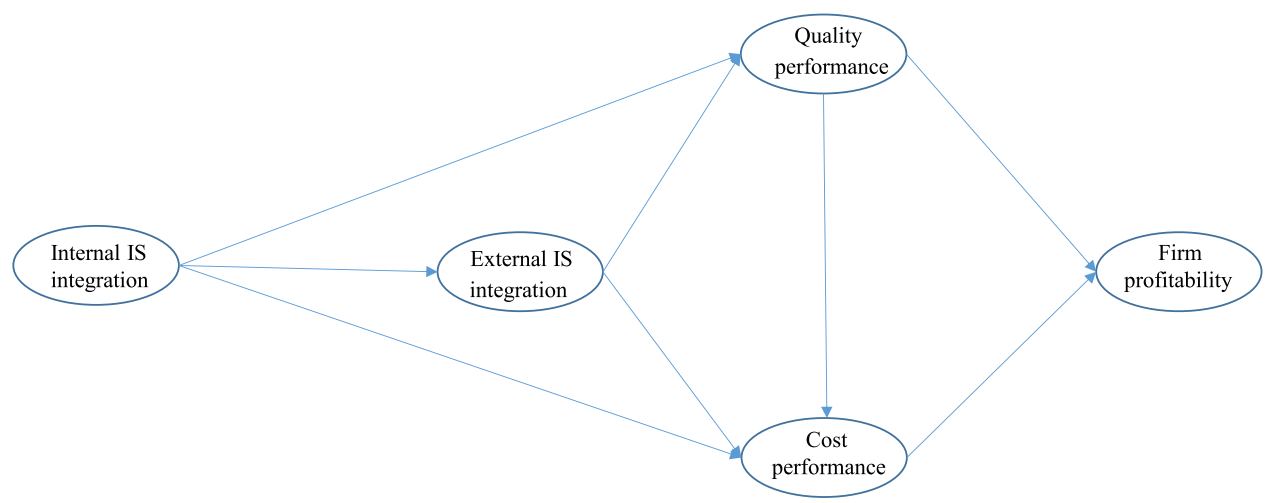

Fig. 1. Conceptual Model.

\subsection{Internal IS integration and external IS integration}

Internal IS integration refers to the electronic linkages of a firm's information technology applications to data acquisition and storage systems that facilitate the sharing of accurate and timely information in support of cross-functional processes (Hammer, 2001). External IS integration involves standardizing and digitizing information exchange spanning cross-organizational business activities (Zhou and Benton, 2007). Such integration makes information available for timely dissemination to relevant supply chain partners for responsive decision making and market actions.

Due to market uncertainties, the lack of timely and pertinent information, and limited know-how, internal constituents seek to integrate with external actors (suppliers and customers). In the absence of a sufficient within-firm IS infrastructure, the quality of the data input for the between-firm IS system is not likely to be satisfactory. By the same token, if a firm does not have good between-firm IS infrastructure in place, it cannot receive updated demand information, supplier information, or customer information needed to support effective within-firm IT systems (Fayard et al., 2012).

Flynn et al. (2010) suggest that the impact of internal integration on external integration can be explained from three major perspectives: information sharing, strategic cooperation or alliance, and working together. They explain that an organization cannot share information and data with its supply chain partners if its own systems are not integrated. They further suggest that without internal integration, the data shared with supply chain partners may not be accurate or timely. The organization also needs to be internally integrated to speak with one voice and develop a coherent strategy and action plan with suppliers and customers. Therefore, we test the following hypothesis:

$\mathbf{H}_{\mathbf{1}}$. Internal IS integration is positively associated with external IS integration.

\subsection{Internal IS integration in relation to cost and quality performance}

A high degree of cross-functional integration suggests intense communication and collaboration among individuals and functional units, such as manufacturing, purchasing, and materials management, increased mutual feedback, and the ability to solve mutual problems together (Giffi et al., 1990; Clark and Wheelwright, 1992; Olson et al., 1995; Song et al., 2000; El Amrani et al., 2006). Internal integration recognizes that different departments and functional areas within a firm should operate as part of an integrated process through information sharing, joint planning, and cross-functional teams. This form of integration breaks down functional barriers and engenders cooperation to meet customer requirements, rather than operating within the functional silos associated with traditional departmentalization and specialization (Flynn et al., 2010). ERP systems are one example of information systems that can be used to generate information and facilitate information sharing within a firm, which can enhance the firm's production capabilities (e.g., Schlie and Goldhar, 1995; Dechow and Mouritsen, 2005).

Cash et al. (1992) argue that in firms where the concept of IS integration plays a strategic role, massive transformation of operational and marketing aspects of the value chain is enabled. Through IS integration, companies can identify, combine, and coordinate appropriate internal resources to improve capabilities across several domains, such as product quality (Iansiti and Clark, 1994; Grant, 1996; Griffin, 1997; Flynn et al., 1999; Verona, 1999; Hsu and Chen, 2004; Yusuf et al., 2004; Swink et al., 2006; Jacobs et al., 2007; Wong et al., 2007). Case-based evidence also suggests that internal integration leads to greater cost reduction (Burt and Doyle, 1993; Ellram and Pearson, 1993; Wong et al., 2011). For example, in a case study of data integration in Texaco and Star Enterprise, Richardson et al. (1990) report the importance of managing data needs as a corporate asset, with data planning an integral part of business process improvements that can be categorized into defect prevention, improvement actions, and cost of quality deficiencies (Crosby, 1979; Deming, 1986; Juran, 1992). Parallel to this study, in a case study with TRW's Space and Defense sector, Railing and Housel (1990) find that integrated communication networks offered cost reductions. Similarly, Palaniswamy and Frank (2000) use case analysis in five manufacturing firms to investigate the manufacturing performance of ERP systems. They find that all the companies benefit from better cross-functional integration.

Reflecting the discussion above, we test the following hypotheses:

$\mathbf{H}_{2}$. Internal IS integration is positively associated with quality performance.

$\mathbf{H}_{3}$. Internal IS integration is positively associated with cost performance.

\subsection{External IS integration in relation to cost and quality performance}

External integration refers to information systems that involve networks that transcend organizations, and the most successful examples in IT systems are those that link a company to its suppliers, distributors, and customers (Gunasekaran and Ngai, 2004. IS integration also involves the sharing of pertinent knowledge and information among members of a supply chain (Prajogo and Olhager, 2012). This may involve sharing design and 
manufacturing data among suppliers, focal manufacturers, and customers (Bardi et al., 1994). Suppliers and customers may be invited to participate in focal company product design teams to capture pertinent upstream and downstream issues in product/ process changes. Consistent with the central tenet of strategic cost management, many costs are "designed in" when buyers and suppliers make decisions about product and process design (Kaplan and Cooper, 1998; Anderson, 2007; Anderson and Dekker, 2009a). Because a large proportion of a product's costs are purchased materials and services, it is natural to include suppliers in the decision-making process (Zsidisin and Smith, 2005).

Prior research notes that organizations that succeed in joint product development for low cost tend to employ novel approaches for sharing relevant information, including integrated information systems for joint problem solving and concurrent engineering (Anderson and Lanen, 2002; Kulp, 2002; Cooper and Slagmulder, 2004). These approaches are critical in the design of products and processes to improve supply chain efficiency (Chen and Paulraj, 2004), but they are also used in cost management of ongoing operations and reduction in production cost (Anderson and Dekker, 2009b). For example, in their case study, Tchokogue et al. (2005) analyze the implementation of SAP R/3 at Pratt \& Whitney Canada (P\&WC). After implementing ERP, the inventory level stabilized and the additional performance enhancement included better customer response time, reduced work-in-process, increased inventory turnover, increased visibility of inventory, and reduced operating costs.

Prior research also notes that the close interrelationship between the manufacturer and its suppliers afforded by IS integration can have significant performance effects in terms of cost (i.e., material costs, labor costs, and other manufacturing costs) (Narasimhan and Jayaram, 1998; Carr and Pearson, 1999; Ragatz et al., 2002; Fynes et al., 2005; Hoegl and Wagner, 2005). IS integration with the customer will also help the manufacturer understand customer requirements and forecast customer demand, thus allowing the manufacturer to provide products at lower costs (Frohlich and Westbrook, 2001; Vickery et al., 2003; Swink et al., 2007; Kim, 2009; Wong et al., 2011). This leads to the following hypothesis:

$\mathbf{H}_{4}$. External IS integration is positively associated with cost performance.

Prior research indicates that close collaboration encourages suppliers to become involved early in the buying firm's design of products/services and to offer suggestions regarding product and/ or component simplification (Kaynak, 2003). IS integration with the customer involves sharing demand information, understanding customer needs, and collaborative involvement of customers with respect to product design and quality performance (Frohlich and Westbrook, 2001; Vickery et al., 2003; Swink et al., 2007). As the main source of new product ideas, customers can provide valuable information in this regard (Prajogo et al., 2008). Thus, close relationships with customers result in a “...compilation of and use of quality information for improving products desired by customers" (Ahire and Ravichandran, 2001, p. 452). More specifically, IS integration with customers helps the manufacturer understand customer requirements and forecast customer demand, thus allowing the manufacturer to provide better quality products (and product functionality and customer satisfaction) (Fynes et al., 2005; Hoegl and Wagner, 2005; Kim, 2009; Flynn et al., 2010; Wong et al. 2011). Consequently, the following hypothesis is proposed:
H5. External IS integration is positively associated with quality performance.

\subsection{Quality performance and cost performance}

Researchers and practitioners in the quality management domain contend that quality performance results in cost savings that more than compensate for the costs of the quality efforts (Slaughter et al., 1998). Quality outputs can lead to a reduction in cost per unit through economies of scale (Kroll et al., 1999). This reasoning is consistent with Deming (1986), who suggests that higher quality leads to lower costs through reductions in, for example, scrap, rework, and defects, and with learning curve theory, which suggests that costs decline more rapidly with the production of high-quality products (Fine, 1983, 1986). Also, one can assume that quality performance serves as a base for cost performance because processes become more stable and reliable, less time and effort are required for rework, and fewer resources must be spent to handle customer complaints and relationships (Ferdows and De Meyer, 1990; Noble, 1995; Kaynak, 2003). In line with learning curve theory, with Ferdows and De Meyer, 1990, and with the strategic cost management literature (Shank and Govindarajan, 1993; Anderson, 2007), the conceptual model put forth here suggests that, ceteris paribus, quality performance leads to cost performance. Therefore, the following hypothesis is tested:

$\mathbf{H}_{6}$. Quality performance is positively associated with cost performance.

\subsection{Quality performance and firm profitability}

The key to successful quality performance is the ability to charge an above-market price, which results from customers' perception that the product is special in some way (Berman et al., 1999). Such an ability to command a premium price can in turn boost firm profitability (Porter, 1980; Kotha and Vadlamani, 1995; Kaynak, 2003). In addition, quality performance can lead to greater market demand, resulting in enhanced firm profitability even with a constant price level per unit.

Empirical work supports the positive direct link between quality performance and firm profitability (Flynn et al., 1994, 1995a, b; Singles et al., 2001; Tsekouras et al., 2002; Wayhan et al., 2002; Kaynak, 2003; Maiga et al., 2013). For example, Tatikonda and Montoya-Weiss (2001) find that product quality does, in fact, translate into financial performance. Kaynak and Hartley (2008) report that high-quality performance tends to lead to higher financial and market performance. Ittner and Larcker (1996), Hendricks and Singhal (2001), and Prajogo and Sohal (2006) also examine the link between quality performance and financial performance and provide evidence that quality performance positively affects firm profitability. Accordingly, we propose that:

H. $_{7}$ Quality performance is positively associated with firm profitability.

\subsection{Cost performance and firm profitability}

Measures of cost-efficiency allow firms to assess their costs per unit of output (Berman et al., 1999). According to Porter (1980), cost performance requires a firm to be constantly improving its ability to produce at costs lower than its competition by means of efficient-scale facilities and vigorously pursuing cost reductions along the value chain, driven by experience, tight cost, and overhead control (Spanos et al., 2004; Wu et al., 2007). This can provide above-average returns because it allows the firm to lower its prices to match those of its competitors while still earning profits 
(Porter, 1980, 1985; Hambrick, 1983; Miller and Friesen 1986; Husted and Allen 2006). Ceteris paribus, a firm that succeeds in driving down costs per unit of output, thereby increasing gross margins, should become increasingly profitable (Porter, 1980; Miller, 1987). Thus, cost performance is expected to transfer business savings to the bottom line (Rust et al., 2002). Therefore:

H8. Cost performance is positively associated with firm profitability.

\subsection{Corollary hypotheses}

Based on the above literature, this study suggests that, to strengthen the advantages in their cost and quality performance, managers should more efficiently leverage IS integration, with the result that cost and quality performance directly enhances their profitability. This is in line with Newbert (2008), who suggests that to generate financial benefits from its resource-capability combination, a firm must first obtain a competitive advantage deriving from its exploitation. Thus, we argue that both internal IS integration and external IS integration are positively associated with cost and quality performance, which in turn are positively associated with firm profitability. In other words, this study suggests that cost and quality performance mediate the effects of IS integration on firm profitability. This leads to the following hypothesis:

H9. Cost and quality performance mediates the effects of IS integration on firm profitability.

\section{Research design and methods}

\subsection{Survey questionnaire and variable measurement}

To test the hypotheses, we employed a survey-based methodology. The survey constructs were developed on the basis of theory and on items proposed and validated in prior studies. From these efforts, several items were generated to measure the different aspects of the constructs. To ensure face validity, content validity, readability, and brevity, we subjected the instruments to a formal assessment by academics with expertise in accounting, manufacturing management, information systems, and marketing. We subsequently revised the instrument to incorporate participants' feedback. The final instrument is discussed below.

Internal IS integration was measured using the following four items: (1) "Our firm's information systems allow continuous monitoring of activities across our firm," (2) "Data can be shared easily among various internal systems within our firm (e.g., forecasting, production, manufacturing, shipment, finance, accounting, etc.)", (3) "Status changes within our firm (such as account balances or forecasts) are automatically reflected within our firm's information systems (e.g., inventory, manufacturing resource planning, and manufacturing systems)", and (4) "Our firm's employees are able to retrieve information from various databases for decision support (e.g., cost information, reporting tools)" (Barua et al., 2004; Fayard et al., 2012).

We also measured external IS integration using four items: (1) "Our firm and our partner firm have information systems that facilitate information exchange across firm boundaries", (2) "Our firm and our partner firm have inter-organizational information systems that support the easy exchange of information", (3) "Our firm's information systems are connected to our partner firm's systems, allowing data to be shared easily between firms", and (4) "Our firm's systems can easily transmit, integrate, and process data with our partner firm" (Vickery et al., 2003; Barua et al., 2004; Fayard et al., 2012).

For all of the above eight items measuring IS integration, participants indicated their agreement with each item statement using a 7-point Likert scale ranging from $1=$ "strongly disagree" to 7 = "strongly agree". As in Fayard et al. (2012), the responses to these items were used to calculate a measured value for each construct. We specifically asked respondents to "consider a business partner, either a customer or a supplier, that is very important to your employer and with whom you are familiar" (ibid., p. 7). In this way, the respondents were asked to focus on those customers or suppliers in a supply chain that were strategically significant.

Quality performance was measured based on responses regarding four aspects of product quality: (1) finished product first-pass quality yield in percentage terms, (2) scrap cost as a percentage of sales, (3) rework cost as a percentage of sales (Ittner et al., 2002), and (4) internal (before shipping) product performance tests showing improved product reliability (Ahire and Dreyfus, 2000).

We measured cost performance using four categories of cost borrowed from the literature (e.g., Ittner et al., 2002): (1) materials cost, (2) labor cost, (3) overhead cost, and (4) non-manufacturing cost.

Firm profitability was measured using the following three items: (1) return on sales (ROS)-net income before corporate expenses divided by sales, (2) turnover on assets (TOA) -sales divided by total assets, and (3) return on assets (ROA). Although interdependent, ROA and ROS reflect different determinants of a business success or failure (Kinney and Wempe, 2002). Atkinson et al. (2001) describe asset turnover as a measure of productivitythe ability to generate sales with a given level of investment-and ROS as a measure of efficiency-the ability to control costs at a given level of sales activity. On all these performance measures, respondents were asked to indicate, on a 7-point Likert-scale ( 1 = "much worse" to 7 = "much better"), how strong they feel their firm had performed relative to their primary/major competitors over the past three years.

\subsection{Sampling frame}

A cross-sectional mail survey was utilized for data collection. The target sample frame consisted of members of the Institute for Supply Management (ISM) drawn from firms covered under the two-digit SIC codes between 20 and 39. We targeted respondents with the following titles: vice president purchasing, vice president materials management, vice president supply chain management or director/manager of purchasing, and director/manager materials and production management.

We randomly selected 1100 firms and mailed the potential respondents we identified from each firm a copy of the questionnaire with a self-addressed, postage-paid envelope for returning the completed questionnaire directly to the researchers. We promised anonymity and described the objectives of the study. To increase the response rate, we sent follow-up letters and another copy of the questionnaire to those who had not responded. Within the first three weeks, we received responses from 212 firms. The second mailing resulted in 75 additional responding firms. Twenty-four firms were eliminated because the questionnaires were returned incomplete, resulting in 263 usable firm responses for a response rate of $23.9 \%$ (263/1100). The survey data were collected in 2014.

\subsection{Non-response bias}

Non-response bias is always a concern in survey research, so we tested for statistical differences in the responses between the 
early and late waves of survey respondents, with the last wave of surveys received considered representative of non-respondents (Armstrong and Overton 1977). T-tests were performed to compare the mean scores of the early and late responses. There were no statistically significant differences between the early and late respondents, providing some assurance concerning non-response bias.

\subsection{Common method bias}

The questionnaire groups questions according to the underlying constructs being tested to facilitate reader understanding. However, control for common method biases was accomplished through design of the study's procedures (procedural remedies), including (a) assuring respondents of anonymity, (b) careful construction of the variable constructs (Podsakoff et al., 2003), and (c) not requiring responses that were self-incriminating or sensitive. In addition, upon collection of the survey data, confirmatory factor analysis (CFA) was used to examine whether common method bias represented a serious problem. A single-factor model in which all the model items were assumed to load on one factor was compared with a five-factor model in which the construct items were assumed to load on the scale or factor they represented. In conducting CFA to test for the possibility of common method bias, the best evaluation measure is the relative noncentrality index (Gerbing and Anderson, 1988). The results of a single-factor model CFA produced a relative noncentrality index of 0.384 , while the relative noncentrality index for the five-factor model was 0.861 . These results suggest that common method bias is not a problem in the study.

\subsection{Measurement model, structural model, and mediation}

To test the substantive hypotheses, we relied on Gerbing and Anderson (1988) two-step paradigm for testing models in which the measurement model is tested first followed by testing of the structural model. The measurement model was examined via LISREL 9.10 using maximum likelihood estimation (Anderson et al., 1987). This included specification of a measurement model consisting of all five latent variables concurrently and the assessment of unidimensionality, convergent and discriminant validity, as well as composite reliability. The measurement model specifies how hypothetical constructs are measured in terms of observed variables (Pijpers et al., 2001; Tan, 2001).

The overall fit of the hypothesized model and unidimensionality was assessed using fit indices from various families of fit criteria, such as the $\chi^{2}$ and its ratio to the model degrees of freedom $\left(\chi^{2} / \mathrm{d} f\right)$, Bentler and Bonnet's (1980) non-normed fit index (NNFI), Bentler's (1980) comparative fit index (CFI), and Steiger and Lind's (1980) root mean square error of approximation (RMSEA) along with its associated confidence interval. Detailed criteria for evaluation of model fit can be found in Byrne (1998), Hu and Bentler (1999), and Raykov and Marcoulides (2000). In summary, to support model fit, a consensus among the following is needed: a $\chi^{2} / \mathrm{d} f<2$; an NNFI $>0.90$ and a CFI $>0.90$; an RMSEA below 0.05 or the left endpoint of its $90 \%$ confidence interval markedly smaller than 0.05 (with this interval not excessively wide; Raykov and Marcoulides (2000), and the expected cross validation index (ECVI) smaller than the ECVI for the saturated model. Convergent validity was examined through the magnitude of item standardized loadings and associated $t$-values. The evaluation of discriminant validity followed Fornell and Larcker (1981) recommendation that the square root of the average variance extracted (AVE) for each construct should exceed all correlations between that construct and other constructs. Reliability estimation is left for last because, in the absence of a valid construct, reliability may not be at all relevant. Composite reliabilities using the methods proposed by Raykov (1997) are used to assess construct reliability.

To test Hypotheses 1-8, a structural model was evaluated. If the model fits the data adequately, the $t$-values of the structural coefficients (i.e., gammas and betas) can be used to test the research hypotheses. Next, mediation effects were tested. To this end, bootstrapping was used to assess whether quality performance and cost performance mediate the effects of internal and external IS integration on firm profitability. Bootstrapping is a statistical resampling method that estimates a model's parameters and their standard errors strictly from the sample (Preacher and Hayes, 2008). Bootstrapping computes more accurate confidence intervals (CIs) of indirect effects than the more commonly used methods, such as the causal steps strategy (Baron and Kenny, 1986) and the Sobel test, as it does not impose the assumption that the sampling distribution is normal (Preacher and Hayes, 2008). This is especially relevant for indirect effects, as these have distributions that are skewed away from zero (Shrout and Bolger, 2002).

\section{Results}

\subsection{Descriptive statistics}

Descriptive statistics about the responding firms appear in Table 1. Panel A of Table 1 provides the distribution of firms in the sample by industry, which shows that the industrial, commercial machinery, computers classification has the highest representation (22.43\%) followed by electronics and electrical equipment (15.97\%) and fabricated metals (10.26\%). Panel B of Table 1 provides the respondents' profiles, while Panel $C$ provides respondents' characteristics as measured by annual sales, number of employees, and length of employment. From the position and tenure entries, it appears that the respondents are quite knowledgeable and experienced, have access to information upon which to generate reliable perceptions, and are otherwise well qualified to provide the information required.

\subsection{Measurement model}

The hypothesized measurement model fit was assessed through some of the most commonly used goodness-of-fit indices (Koufteros and Marcoulides, 2006). The results are reported in Table 2. The NNFI was 0.985 and CFI was 0.988 , while the $\chi^{2}$ per degree of freedom was 1.505 . The RMSEA was 0.044 with a $90 \%$ confidence interval of 0.031-0.055, and the model ECVI (1.178) is smaller than the ECVI for the saturated model (1.445), indicating that the measurement model had acceptable fit indices and subsequently is indicative of unidimentionality.

Next, the validity of the constructs was assessed in terms of convergent validity and discriminant validity. Convergent validity essentially examines the magnitude of correlations between item measures of a construct (Gefen, 2003). All manifest indicators had substantive and statistically significant relationships with their respective latent variables, supporting convergent validity. All pair correlations were significant, and the highest correlation between any pair of constructs is 0.450 (between quality performance and cost performance), while the lowest square root of AVE is 0.771 (for profitability). Therefore, discriminant validity can be asserted. Tables 2 and 3 indicate that the AVE of each construct exceeds the variance attributable to its measurement error and that all $\rho$ coefficients for internal consistency are above the 0.70 threshold. All composite reliability estimates and AVEs exceed customary acceptable levels (Raykov, 1997). Therefore, the posited 
Table 1

Descriptive statistics.

\begin{tabular}{|c|c|c|c|}
\hline \multicolumn{4}{|c|}{ Panel A: Distribution of firms in sample by industry } \\
\hline & SIC & $\begin{array}{l}\text { Number of } \\
\text { firms in } \\
\text { sample }\end{array}$ & $\begin{array}{l}\% \text { Of sample } \\
(n=263)\end{array}$ \\
\hline Food and products & 20 & 7 & 2.662 \\
\hline Tobacco product & 21 & 0 & 0.000 \\
\hline Textile mill products & 22 & 9 & 3.422 \\
\hline Lumber and wood & 24 & 5 & 1.901 \\
\hline Furniture and fixtures & 25 & 3 & 1.141 \\
\hline Paper & 26 & 7 & 2.662 \\
\hline Printing and publishing & 27 & 3 & 1.141 \\
\hline Chemicals & 28 & 25 & 9.506 \\
\hline Petroleum and coal & 29 & 1 & 0.380 \\
\hline Rubber and misc. plastic & 30 & 11 & 4.183 \\
\hline Stone, clay, and glass & 32 & 4 & 1.521 \\
\hline Primary metal & 33 & 9 & 3.422 \\
\hline Fabricated metals & 34 & 27 & 10.266 \\
\hline \multicolumn{4}{|l|}{ Industrial, commercial } \\
\hline \multicolumn{4}{|l|}{ Electronics and electrical } \\
\hline equipment & 36 & 42 & 15.970 \\
\hline Transportation equipment & 37 & 25 & 9.506 \\
\hline $\begin{array}{l}\text { Instruments and related } \\
\text { products }\end{array}$ & 38 & 23 & 8.745 \\
\hline Other & 39 & 3 & 1.141 \\
\hline Total & & 263 & 100.000 \\
\hline \multicolumn{4}{|l|}{ Panel B: Respondent profile } \\
\hline Title & $\begin{array}{l}\text { Number of } \\
\text { respondents }\end{array}$ & Percentage & \\
\hline \multicolumn{4}{|l|}{ President/vice president } \\
\hline $\begin{array}{l}\text { Supply chain } \\
\text { management }\end{array}$ & 32 & 12.167 & \\
\hline \multicolumn{4}{|l|}{ management } \\
\hline Purchasing & 21 & 7.985 & \\
\hline \multicolumn{4}{|l|}{ Director } \\
\hline Purchasing & 25 & 9.506 & \\
\hline Procurement & 28 & 10.646 & \\
\hline Materials & 23 & 8.745 & \\
\hline \multicolumn{4}{|l|}{ management } \\
\hline \multicolumn{3}{|l|}{ management } & \\
\hline Operations & 24 & 9.125 & \\
\hline \multicolumn{4}{|l|}{ Manager } \\
\hline $\begin{array}{l}\text { Supplier } \\
\text { development }\end{array}$ & 19 & 6.844 & \\
\hline Operations & 11 & 4.183 & \\
\hline Marketing & 15 & 5.703 & \\
\hline Total & 263 & 100 & \\
\hline
\end{tabular}

Panel C: Other characteristics of respondents

\section{C1. Annual sales}

$<\$ 100$ million

$\$ 101$ million-\$499,000

million

$\$ 500$ million-\$999,000

million

$\$ 1$ billion - \$4.99 billion

$>\$ 5$ billion

Total

C2. Number of employees

$<1000$

1001-2000

2001-3000

$3001-4000$

4001-5000

$>5000$

Total

C3. Length of employment

$0-5$ years

6-10 years
Number of responding firms

\section{9}

67

89

31

27

263

41
78

78
51

51
39

23

31
263

Number of

respondents

42

107
Table 1 (continued)

\begin{tabular}{lll}
\hline $11-15$ years & 71 & 26.996 \\
$16-20$ years & 33 & 12.548 \\
Over 20 years & 9 & 3.422 \\
Total & 263 & 100 \\
\hline
\end{tabular}

measurement model was supported when scrutinized for model fit, unidimensionality, convergent and discriminant validity, and latent variable composite reliability. Overall, there is sufficient support for the model to allow us to proceed with an evaluation of the structural model and detailed hypotheses testing.

\subsection{Structural model}

Before the structural coefficients are assessed, the fit of the structural model should be examined to ascertain whether the model can adequately represent the data. The $\chi^{2}$ per degree of freedom was 1.518 and NNFI and CFI were 0.955 and 0.987, respectively, while RMSEA and its $90 \%$ confidence interval were 0.044 and $0.032-0.055$, respectively. The model ECVI (1.181) is smaller than the ECVI for the saturated model (1.445). Overall, these fit indices suggest good model fit (Table 4).

Next, we examine the standardized parameter estimates for our model by using the significance of individual path coefficients to evaluate the hypotheses. Consistent with the prior literature and empirical studies, $\mathrm{H}_{1}$ hypothesized that internal IS integration was a precursor to external IS integration. The results supported this hypothesis (Table 4, Fig. 2). Specifically, higher levels of internal IS integration were associated with higher levels of external IS integration $(\gamma=0.421, t=5.114, p<0.001)$. These findings suggest that internal IS integration may be conducive for external IS integration (Fayard et al., 2012). They may also suggest that the best approach to IS integration is to start by developing internal IS integration capabilities and then build external integration capabilities.

In support of $\mathrm{H}_{2}$ and $\mathrm{H}_{3}$, the results indicate that higher levels of internal IS integration were related to higher levels of quality performance and cost performance $(\gamma=0.216, t=2.741, p<0.01$; $\gamma=0.182, t=2.456, p<0.01$, respectively). The analysis suggests that internal IS integration has a positive effect on an organization's ability to achieve higher levels of cost and quality performance, attesting to the importance of internal IS integration. External IS integration also affected both quality performance and cost performance $(\beta=0.318, \quad t=3.824, \quad p<0.001 ; \quad \beta=0.163, \quad t=2.156$, $p<0.01$, respectively), supporting $\mathrm{H}_{4}$ and $\mathrm{H}_{5}$. The path coefficient indicates positive effects, signifying that external IS integration is a vital explanatory variable. Collectively, managing IS integration both internally and externally contributes beneficially to cost and quality performance. Similarly, in support of $\mathrm{H}_{6}$ and $\mathrm{H}_{7}$, the effects of quality performance on both cost performance $(\beta=0.319, t=4.245$, $p<0.001)$ and firm profitability $(\beta=0.320, t=3.386, p<0.001)$ are significantly positive. Also, cost performance is significantly positively associated with firm profitability $(\beta=0.280, t=3.149$, $p<0.001$ ), supporting $\mathrm{H}_{8}$. Thus, Hypotheses 1 through 8 are supported. Table 4 and Fig. 2 show the estimates and significance of the hypothesized paths for the conceptual model.

\subsection{Testing of corollary hypotheses-mediation}

The mediation hypothesis concerns whether quality performance and cost performance mediate the effect of internal and external IS integration on profitability $\left(\mathrm{H}_{9}\right)$. Indirect effects were investigated to test the mediating role of quality and cost performance. Consequently, bootstrapped confidence interval estimates 
Table 2

Results of factor analysis and validity check.

\begin{tabular}{|c|c|c|c|c|c|}
\hline Construct and items & Mean (SD) & $\begin{array}{l}\text { Standardized } \\
\text { loading }\end{array}$ & $T$-value & $\rho$ & $\begin{array}{l}\text { Average variance } \\
\text { extracted }\end{array}$ \\
\hline Internal IS integration & & & & 0.818 & 0.653 \\
\hline $\begin{array}{l}\text { INTERNAL1-Our firm's information systems allow continuous monitoring of activities } \\
\text { across our firm. }\end{array}$ & $3.517(1.217)$ & 0.783 & 11.965 & & \\
\hline $\begin{array}{l}\text { INTERNAL2-Data can be shared easily among various internal systems within our firm } \\
\text { (e.g. forecasting, production, manufacturing, shipment, finance, accounting, etc.). }\end{array}$ & $4.118(1.128)$ & 0.715 & 11.055 & & \\
\hline $\begin{array}{l}\text { INTERNAL3-Status changes within our firm (such as account balances or forecasts) are } \\
\text { automatically reflected within our firm's information systems (e.g. inventory, manu- } \\
\text { facturing resource planning, and manufacturing systems). }\end{array}$ & $4.369(1.391)$ & 0.647 & 9.978 & & \\
\hline $\begin{array}{l}\text { INTERNAL4-Our firm's employees are able to retrieve information from various data- } \\
\text { bases for decision support. }\end{array}$ & $3.608(1.176)$ & 0.787 & $-{ }^{*}$ & & \\
\hline External IS integration & & & & 0.838 & 0.685 \\
\hline $\begin{array}{l}\text { EXTERNAL1-Our firm and our partner firm have information systems that facilitate } \\
\text { information exchange across firm boundaries. }\end{array}$ & $3.653(1.248)$ & 0.853 & 15.333 & & \\
\hline $\begin{array}{l}\text { EXTERNAL2-Our firm and our partner firm have inter-organizational information sys- } \\
\text { tems that support the easy exchange of information. }\end{array}$ & $3.966(1.661)$ & 0.821 & 14.760 & & \\
\hline $\begin{array}{l}\text { EXTERNAL3-Our firm's information systems are connected to our partner firm's sys- } \\
\text { tems, allowing data to be shared easily between firms. }\end{array}$ & $3.402(1.078)$ & 0.640 & 8.851 & & \\
\hline $\begin{array}{l}\text { EXTERNAL4-Our firms systems can easily transmit, integrate, and process data with our } \\
\text { partner firm. }\end{array}$ & $4.158(1.193)$ & 0.829 & - & & \\
\hline Quality performance & & & & 0.830 & 0.664 \\
\hline QUALITY1-Finished product first pass quality yield in percentage term & $3.709(1.386)$ & 0.696 & 10.706 & & \\
\hline QUALITY2-Scrap cost as a percentage of sales & $3.548(1.290)$ & 0.773 & 11.813 & & \\
\hline QUALITY3-Rework as a percentage of sales & $4.411(1.251)$ & 0.735 & 11.285 & & \\
\hline $\begin{array}{l}\text { QUALITY4-Our internal (before shipping) product performance tests have shown } \\
\text { improved product reliability over the past three years }\end{array}$ & 3.510 (1.309) & 0.771 & - & & \\
\hline Cost performance & & & & 0.905 & 0.781 \\
\hline COST1-Materials cost & $3.809(1.377)$ & 0.847 & 17.170 & & \\
\hline COST2-Labor cost & $4.229(1.212)$ & 0.814 & 16.143 & & \\
\hline COST3-Overhead cost & $3.457(1.247)$ & 0.843 & 17.058 & & \\
\hline COST4-Nonmanufacturing cost & $4.186(1.131)$ & 0.862 & - & & \\
\hline Firm Profitability & & & & 0.756 & 0.594 \\
\hline PROFIT1-Return on sales & $4.199(1.043)$ & 0.602 & 6.347 & & \\
\hline PROFIT2-Turnover on assets & $3.920(1.007)$ & 0.752 & 6.525 & & \\
\hline PROFIT3-Return on assets & $3.749(0.943)$ & 0.649 & - & & \\
\hline
\end{tabular}

Notes: $-{ }^{*}$ indicates a fixed scaling parameter.

All loadings are significant at $p<0.001$.

Fit indices: $\chi^{2}(\mathrm{df})=213.747 / 142=1.505$; model AIC $=2879.913$, saturated model $=2950.166$; $\mathrm{NFI}=$.

956; $\mathrm{NNFI}=0.985 ; \mathrm{CFI}=0.988$; $\mathrm{RMSEA}=0.044$.

Model fit (suggested cutoff points of the fit measures): Chi-square/d.f. $<2$, RMSEA $<0.05$, NFI $>0.90$.

NNFI > 0.90; CFI > 0.90, (Hair et al 1995).

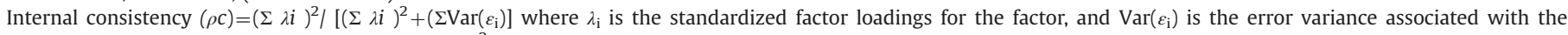
individual indicator variables, where $\operatorname{Var}\left(\varepsilon_{\mathrm{i}}\right)=\left(1-\lambda_{i}^{2}\right)$ (Fornell and Larcker, 1981).

Average variance extracted $=\Sigma \lambda i^{2} /\left(\Sigma \lambda i^{2}+\Sigma \operatorname{Var}\left(\varepsilon_{\mathrm{i}}\right)\right)$ (Fornell and Larcker, 1981).

Table 3

Correlations of latent variables.

\begin{tabular}{llllll}
\hline & 1 & 2 & 3 & 4 & 5 \\
1. Internal IS integration & $\mathbf{0 . 8 0 8}^{\text {a }}$ & & & & \\
2. External IS integration & 0.421 & $\mathbf{0 . 8 2 8}$ & & & \\
Quality performance & 0.349 & 0.409 & $\mathbf{0 . 8 1 5}$ & & \\
4. Cost performance & 0.362 & 0.370 & 0.450 & $\mathbf{0 . 8 8 4}$ & \\
5. Profitability & 0.213 & 0.234 & 0.446 & 0.423 & $\mathbf{0 . 7 7 1}$
\end{tabular}

Notes: All correlations are significant at $p<0.001$.

a Square root of the average variance extracted is on the diagonal.

of the indirect effect (see Preacher and Hayes (2008)) were calculated to confirm the significance of mediations. Bootstrapping randomly constructs a number of resamples of the original sample to estimate parameters. In the present study, the $95 \%$ confidence interval of the indirect effects was obtained with 5000 bootstrap resamples (Shrout and Bolger, 2002). Note that the indirect effect is significant at $p<0.05$ if the $95 \%$ confidence intervals do not include the value of zero. In the present study, the confidence interval was bias corrected given that this correction is believed to improve power and Type 1 error rates (MacKinnon et al., 2004).
Table 4

Summary of standardized structural model parameter estimates.

\begin{tabular}{|c|c|c|c|c|}
\hline Path* & $\begin{array}{l}\text { Internal IS } \\
\text { integration }\end{array}$ & $\begin{array}{l}\text { External IS } \\
\text { integration }\end{array}$ & $\begin{array}{l}\text { Quality } \\
\text { performance }\end{array}$ & $\begin{array}{l}\text { Cost } \\
\text { performance }\end{array}$ \\
\hline $\begin{array}{l}\text { External IS } \\
\text { integration }\end{array}$ & $\begin{array}{l}\mathrm{H}_{1}: \gamma=0.421 \\
(t=5.114)\end{array}$ & & & \\
\hline $\begin{array}{l}\text { Quality } \\
\text { performance }\end{array}$ & $\begin{array}{l}\mathrm{H}_{2}: \gamma=0.216 \\
(t=2.741)\end{array}$ & $\begin{array}{l}\mathrm{H}_{4}: \beta=0.318 \\
(t=3.824)\end{array}$ & & \\
\hline $\begin{array}{l}\text { Cost } \\
\text { performance }\end{array}$ & $\begin{array}{l}\mathrm{H}_{3}: \gamma=0.182 \\
(t=2.456)\end{array}$ & $\begin{array}{l}\mathrm{H}_{5}: \beta=0.163 \\
(t=2.156)\end{array}$ & $\begin{array}{l}\mathrm{H}_{6}: \beta=0.319 \\
(t=4.245)\end{array}$ & \\
\hline Profitability & - & - & $\begin{array}{l}\mathrm{H}_{7}: \beta=0.320 \\
(t=3.386)\end{array}$ & $\begin{array}{l}\mathrm{H}_{8}: \beta=0.280 \\
(t=3.149)\end{array}$ \\
\hline
\end{tabular}

Fit indices: $\chi^{2} / \mathrm{df}=1.516$; $\mathrm{NNFI}=0.955 ; \mathrm{CFI}=0.987$; $\mathrm{RMSEA}=0.044$ with $90 \%$ confidence interval of $0.032-0.056$; model $E C V I=1.180$; saturated model $=1.445$.

* All $t$-values are significant.

We assessed all the possible indirect effects of internal and external IS integration on profitability. The bootstrapping results presented in Table 5 confirm that all the indirect pathways were significant. Therefore, the results support $\mathrm{H}_{9}$. Hence, interpreting the findings, we can assert that both quality performance and cost performance completely mediate the effects of internal and external IS integration on profitability. 


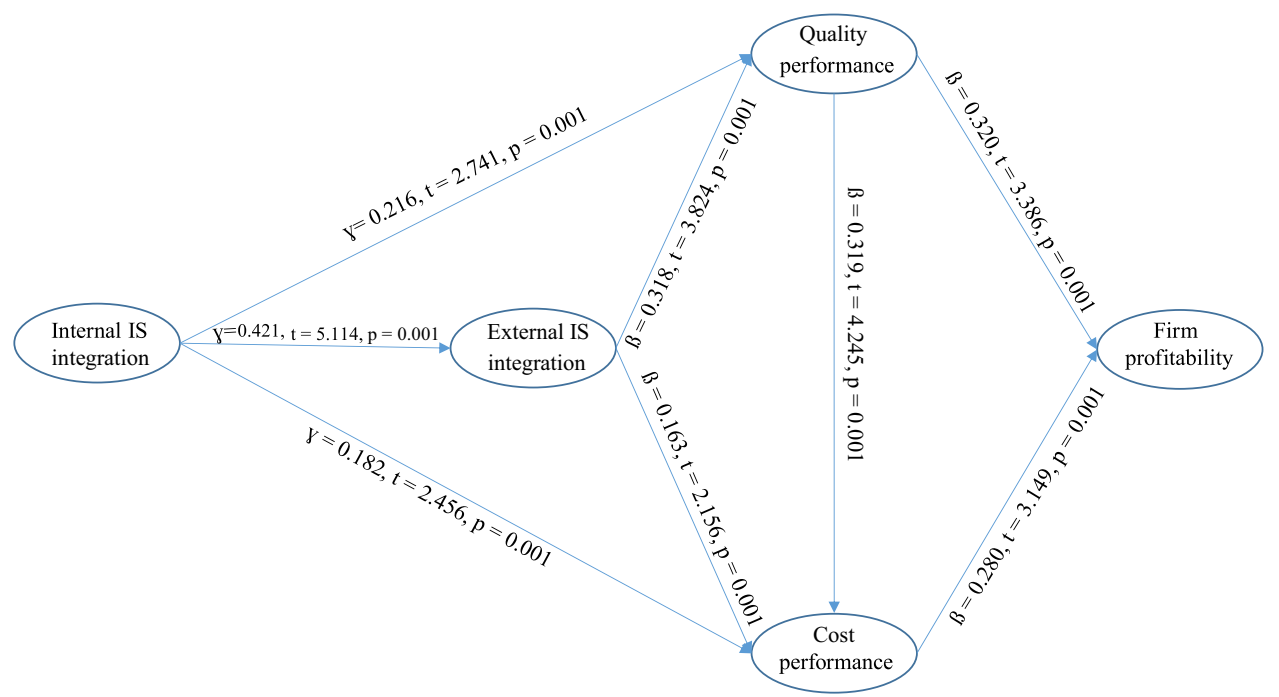

Fig. 2. Standardized structural path coefficients.

Table 5

Testing of the mediation effects of quality performance and cost performance.

\begin{tabular}{|c|c|c|c|c|}
\hline \multirow[t]{2}{*}{ From $->$ To } & \multirow[t]{2}{*}{ Standardized indirect effect } & \multirow[t]{2}{*}{ S.E. } & \multicolumn{2}{|c|}{ 95\% CI for standardized indirect effect } \\
\hline & & & Lower & Upper \\
\hline IIS integration - Quality Performance - Profitability & $0.071^{*}$ & 0.019 & 0.012 & 0.102 \\
\hline IIS integration - Quality performance - Cost performance - Profitability & $0.019^{\text {*** }}$ & 0.008 & 0.003 & 0.063 \\
\hline IIS integration - EIS integration - Quality performance - Profitability & $0.051^{*}$ & 0.017 & 0.012 & 0.113 \\
\hline IIS integration - EIS integration - Quality performance - Cost performance - Profitability & $0.013^{\text {***** }}$ & 0.005 & 0.001 & 0.023 \\
\hline IIS integration - EIS integration - Cost performance - Profitability & $0.043^{*}$ & 0.012 & 0.007 & 0.095 \\
\hline EIS integration - Quality performance - Profitability & $0.010^{* * * *}$ & 0.005 & 0.003 & 0.032 \\
\hline EIS integration - Quality performance - Cost performance - Profitability & $0.031 * *$ & 0.013 & 0.010 & 0.062 \\
\hline EIS integration - Cost performance - Profitability & $0.047^{*}$ & 0.015 & 0.007 & 0.091 \\
\hline
\end{tabular}

Note: IIS=internal IS Integration; EIS=external IS; S.E.=standard error; $\mathrm{CI}=$ confidence interval

$* p<0.001$.

** $p<0.01$.

$* * * * 0.05$

\section{Discussion}

With the growing access to IS, it is crucial for firms to understand how to implement IS investments effectively and use IS as a means to achieve greater firm profitability (Becker et al., 2009). This study aimed to improve the understanding of the link between IS integration and firm profitability. Based on the extant literature, we set out to test whether IS integration can improve firm cost and quality performance to obtain an ultimate increase in firm profitability.

More specifically, using structural equation modeling techniques, this study examined the relationships among internal IS integration, external IS integration, quality performance, cost performance, and firm profitability. The overall contribution of the study is that it provides evidence of the importance of considering all the variables and their interrelationships to positively influence financial performance. While previous studies provide support for some of the relationships, this study reveals a set of interrelationships including quality and cost performance which, taken together, can be decisive in attaining firm profitability from IS integration.

The results of this study indicate that internal IS integration is an important enabler of external IS integration. This finding is consistent with Fayard et al. (2012) and supports Ward and Zhou (2006), who found a positive relationship between within-firm and between-firm IT integration, and Gimenez and Ventura
(2005), who found joint planning and working internally across logistics and production functions to be related to joint planning and external work with supply chain partners.

The results of this study also suggest that internal integration and external IS integration are positively associated with quality and cost performance, which in turn are positively associated with firm profitability. This suggests that IS integration can provide access to know-how, information, mutual understanding, and sharing of resource endowments. This can lead to an enhanced ability to meet customer expectations in introducing high-quality products at low cost. These results support general observations in the literature concerning the importance of IS integration for cost and performance management in the supply chain (Anderson, 2007; Anderson and Dekker, 2009b; Chapman and Kihn, 2009; Coad and Cullen, 2006; Fayard et al., 2012; Holweg and Pil, 2008; Hopwood, 1996; Ward and Zhou, 2006) and for quality performance (Fynes et al., 2005; Hoegl and Wagner, 2005; Kim, 2009; Flynn et al., 2010; Wong et al., 2011).

On the effects of quality performance on firm profitability, our results corroborate prior studies in the accounting information systems literature suggesting a significant positive association between the two variables (e.g., Maiga et al., 2013). These results are also in line with anecdotal evidence (e.g., Sankar, 1995) and prior empirical findings in operations management (e.g., Dale and Lightburn, 1992; Voss and Blackmon, 1994). Our results on the association between cost performance and profitability support 
previous studies suggesting that since cost reduction programs transfer their savings directly to the bottom line (Rust et al., 2002), lower agency and transaction costs can be associated with greater potential for economies of scale and capturing value-added and margins (Harrigan, 1985) while also increasing profits (Gatignon and Xuereb, 1997).

Overall, our findings reveal that the link between IS integration and firm profitability is positively associated with cost and quality performance. The findings also suggest that cost and quality performance enabled by IS integration are positively associated with firm profitability. This latter observation will be of particular interest to managers and management accountants interested in the performance implications of cost and quality management The lack of significant direct paths between IS integration and profitability and the significance of the indirect effects point to interesting indirect and significant effects of both internal and external IS integration on firm profitability. While this finding needs further research, the results imply that managers must be adept at managing IS integration and make investments in IS to increase cost and quality performance in a way that can be translated to the bottom line.

Our findings also provide much needed guidance to managers of firms that consider their IT integration to be deficient. Instead of assessing the direct implication of IT integration on firm profitability, managers should evaluate the impact of IT integration directly on cost and quality performance and indirectly on firm profitability. Our finding that cost and quality performance fully mediates the relationship between IS integration and firm profitability suggests that managers should use IS to achieve better performance. It is only when managers utilize IS integration in relation to operations that profitability results. Therefore, firms should ensure that managers appreciate the importance of integration of IS internally and externally and recognize how each specific aspect of IT integration can be used to improve their operations. Our results also indicate that managers must pay careful attention to the sequential relationships among IS integration, cost and quality performance, and firm profitability and that they should pay close attention to the development and maintenance of these relational attributes.

Future research should identify the mechanisms through which IS integration can be achieved and subsequently flourish. In other words, what are the organizational drivers for IS integration? What can the organization do to integrate effectively internally and externally? Perhaps the answer lies with organizational design. For instance, the degree of formalization in the organization can restrict the flow of information vertically and horizontally and this makes integration more difficult. Formalization can also restrict the kind of information and data that can be shared and communicated, leading to integration challenges. The number of hierarchical levels in the organization may also play a role. Organizations with too many levels may find it difficult to integrate internally, let alone externally. There is a higher chance that information that passes through multiple levels is distorted, delayed, or does not ever reach its intended recipients. Similarly, when the organization is described by its high centralization of decision-making authority, integration may be more difficult to achieve as decisions must be constantly referred to higher levels before any actions or strategies emerge. A high degree of specialization may also work against integration because specialists may have more domain-specific knowledge/information and lack understanding of organizational processes across functional boundaries.

As in any empirical study, this study has limitations. First, though care was taken to validate the data through psychometric analyses which did not indicate any violations of scale validity, potential self-selection bias in the survey method can never be completely ignored and should be taken into account. Second, identifying other variables that have an intervening effect on the relationship between IS integration and firm profitability may provide both the academic and practitioner communities with potentially compelling answers to the question of why IS integration programs do not always succeed. Third, no cross-sectional study can definitively determine causality. Future research should perform longitudinal studies that investigate firm profitability before and after IS integration with care taken to control for business unit-specific conditions. Fourth, this paper does not address the utility of information in the context of the organizational structure (e.g., Gibbons et al., 2010). As Shin et al. (2012) indicate, it is possible that firm information needs may be influenced by the internal (e.g., functional versus integrated production functions) and external (e.g., complexity of client-firm relations) organization structure and these structures may affect profitability and IS integration as well as costs and quality. Exploring the ways in which organizational structure potentially comes into play represents a promising avenue for future research. Finally, the study can be construed as unconditional in that more IS integration, internal and external, is always better. However, because integration is also a costly exercise, its effect on firm performance may be conditional on factors/considerations that make integration more valuable. Future research can examine such factors/ considerations to shed light on the circumstances in which integration will most likely affect performance positively.

Despite the limitations, the results of this study suggest that our path analytical model offers a useful way to approach IS integration. These findings are of particular interest to managers because of the critical importance of profitability to managers. The results should also be useful to an audience of practitioners and academics interested in firm profitability from IS integration. The conceptual model on which this study is based should also be useful in the development of more detailed models and for future empirical work with different sampling and industries.

\section{References}

Ahire, S.L., 1996. An empirical investigation of quality management in small firms. Prod. Invent. Manag. J. 2, 44-50.

Ahire, S., Dreyfus., P., 2000. The impact of design management and process management on quality: An empirical investigation. J. Oper. Manag. 18, 549-575.

Ahire, S.L., Ravichandran., T., 2001. An innovation diffusion model of TQM implementation. IEEE Trans. Eng. Manag. 48, 445-464.

Amit, R.H., Schoemaker., P.J.H., 1993. Strategic assets and organizational rent. Strateg. Manag. J. 14 (1), 33-46.

Anderson, E.L. Lodish, Weitz, B., 1987. Resource allocation behavior in conventional channels. J. Mark. Res. 24, 85-97.

Anderson, S.W., 2007. Managing costs and cost structure throughout the valuechain: Research on strategic cost management. In: Chapman, C.S., Hopwood, A.G., Shields, M.D. (Eds.), Handbook of Management Accounting Research. Elsevier, Oxford, pp. 481-505.

Anderson, S.W., Dekker., H.C., 2009a. Strategic cost management in supply chains, Part 1: Structural cost management. Account. Horiz. 23 (2), 201-220.

Anderson, S.W., Dekker., H.C., 2009b. Strategic cost management in supply chains, Part 2: Executional cost management. Account. Horiz. 23 (3), 289-305.

Anderson, S.W., Lanen., W.N., 2002. Using electronic data interchange (EDI) to improve the efficiency of accounting transactions. Account. Rev. 77 (4), 703-729.

Armstrong, J.S., Overton., T.S., 1977. Estimating nonresponse bias in mail surveys J. Mark. Res. 4, 396-402.

Atkinson, A.A., Banker, R.D., Kaplan, R.S., Young, S.M., 2001. Management Accounting, 3rd ed. Prentice-Hall, Upper Saddle River, NJ.

Banker, R. D., and R. J. Kauffman., 1988. Strategic contributions of Information technology: An empirical study of ATM networks. In: Proceedings of the 9th International Conference on Information Systems. pp. 141-150.

Bardi, E.J., Raghunathan, T.S., Bagchi., P.K., 1994. Logistics information systems: the strategic role of top management. J. Bus. Logist. 15 (1), 71-85.

Barney, J., 1991. Firm resources and sustained competitive advantage. J. Manag. 17, 99-120.

Baron, R.M., Kenny., D.A., 1986. The moderator-mediator variable distinction in social psychological research: conceptual, strategic, and statistical consideration. J. Personal. Soc. Psychol. 51, 1173-1182. 
Barua, A., Kriebel, C., Mukhopadhyay, T./, 1995. Information technology and business value: an analytic and empirical investigation. Inf. Syst. Res. 6, 3-24 (1).

Barua, A., Konana, P., Whinston., A., 2004. An empirical investigation of net-enabled business value. MIS Q. 28, 585-620.

Becker, J.U., Greve, G., Albers., S., 2009. The impact of technological and organizational implementation of CRM on customer acquisition, maintenance, and retention. Int. J. Res. Mark. 26 (3), 207-215.

Benjamin, R., D. W. De Long, M. S. Scott-Morton., 1988. The realities of electronic data interchange: how much competitive advantage? CISR, WP No. 166, Sloan School of Management, MIT, Mass.

Bentler, P., 1980. Multivariate analysis with latent variables: causal modeling. Annu. Rev. Psychol. 31, 419-456.

Bentler, P.M., Bonnet., D.G., 1980. Significance tests and goodness-of-fit in the analysis of covariance structures. Psychol. Bull. 88, 588-600.

Bergeron, F., Raymond., L., 1992. The advantages of electronic data interchange. Data-Base 23, 19-31.

Berman, S.L., Wicks, A.C., Kotha, S., Jones., T.M., 1999. Does stakeholder orientation matter? The relationship between stakeholder management models and firm financial performance. Acad. Manag. J. 42 (5), 488-508.

Bharadwaj, A., 2000. A resource-based perspective on information technology capability and firm performance: An empirical investigation. MIS Q. 24 (1), 169-196.

Burt, D.N., Doyle., M.F., 1993. The American Keiretsu: A Strategic Weapon for Global Competitiveness. Irwin, IL, Homewood.

Byrne, B., 1998. Structural Equation Modeling with LISREL, PRELIS, and SIMPLIS: Basic Concepts, Applications and Programming. Lawrence Erlbaum Associates Inc., Mahwah, NJ.

Carr, A.S., Pearson., J.N., 1999. Strategically managed buyer-supplier relationships and performance outcomes. J. Oper. Manag. 17 (5), 497-519.

Chapman, C.S., Kihn., L.A., 2009. Information system integration, enabling control and performance. Account. Organ. Soc. 34, 151-169.

Cash, J., McFarlan, F.W., McKenney, J., Applegate., L., 1992. A Portfolio Approach to IT development. Corporate Information Systems Management, 3rd ed. Irwin Publishing, Homewood, IL.

Chan, L.M., Shaffer, M.A., Snape., E., 2004. In search of sustained competitive advantage: the impact of organizational culture, competitive strategy and human resource management practices on firm performance. Int. J. Hum. Resour. Manag. 15 (1), 17-35.

Chen, I.J., Paulraj., A., 2004. Understanding supply chain management: critical research and theoretical framework. Int. J. Prod. Res. 42 (1), 131-163.

Clark, K.B., Wheelwright., S.C., 1992. Organizing and leading heavyweight development teams. Calif. Manag. Rev. 34 (3), 9-28.

Clemons, E., 1986. Information systems for sustainable competitive advantage. Inf. Manag. 11, 131-136.

Clemons, E.K., Weber., B.W., 1990. London's big bang: a case study. J. Manag. Inf. Syst. 6 (4), 41-60.

Clemons, E., M. M. Row., 1988. Cash management accounts: a case study in strategic information systems. In: Proceedings of the 21st Hawaii International Conference on System Sciences, IEEE Computer Society Press, Los Alamitos, CA, pp. 131-140.

Coad, A.F., Cullen., J., 2006. Inter-organizational cost management: towards an evolutionary perspective. Manag. Account. Res. 17, 342-369.

Cooper, R., Slagmulder, R., 2004. Inter-organizational cost management and relational context. Accounting, Organizations and Society 29, 1-26.

Crosby, P., 1979. Quality is Free. McGraw-Hill, New York.

Crosby, P.B., 1996. Quality is Still Free. McGraw-Hill, New York, NY.

Dale, B.G., Lightburn., K., 1992. Continuous quality improvement: why some organizations lack commitment. Int. J. Prod. Econ. 27 (1), 57-67.

D’Souza, D., Williams, E., F.P., 2000. Toward a taxonomy of manufacturing flexibility dimensions. J. Oper. Manag. 18, 577-583.

Das, T.K., Teng., B.S., 2000. A resource-based theory of strategic alliances. J. Manag. 26 (1), 31-61.

Davenport, T.H., 1998. Putting the enterprise into the enterprise system. Harv. Bus. Rev. 121-131.

Davenport, T.H., 2000. Mission critical-realizing the promise of enterprise systems. Harvard Business School Press, Boston (MA) 2000.

Davenport, T.H., Harris, J.G., Cantrell., S., 2004. Enterprise systems and ongoing process change. Bus. Process Manag. J. 10 (1), 16-26.

Dawson, P., Patrickson., M., 1991. Total quality management in Australian banking industry. Int. J. Qual. Reliab. Manag. 8 (5), 66-76.

Dechow, N., Mouritsen., J., 2005. Enterprise resource planning systems, management control and the quest for integration. Account. Organ. Soc. 30 (7-8), 691-733.

Deming, W. E., 1986. Out of the crisis. Cambridge, MA: MIT Center for Advanced Engineering.

Drury, C.G., 2000. Global quality: linking ergonomics and production. Int. J. Prod. Res. 38 (17), 4007-4018.

Eisenhardt, K.M., Martin., J.A., 2000. Dynamic capabilities: what are they? Strateg. Manag. J. 21, 1105-1121.

El Amrani, R., Rowe, F., Geffroy-Maronnat., B., 2006. The effects of enterprise resource planning implementation strategy on cross-functionality. Inf. Syst. J. 16 (1), 79-104.

Ellram, L.M., Pearson., J.N., 1993. The role of the purchasing function: toward team participation. Int. J. Purch. Mater. Manag. 29 (3), 3-9.

Fayard, D., Lee, L.S., Leitch, R.A., Kettinger., W.J., 2012. Effect of internal cost management, information systems integration, and absorptive capacity on inter- organizational cost management in supply chains. Account. Organ. Soc. 37, 168-187.

Ferdows, K., De Meyer., A., 1990. Lasting improvements in manufacturing performance: in search of a new theory. J. Oper. Manag. 9 (2), 168-183.

Fine, C.H., 1983. Quality Learning and Learning in Production Systems. Graduate School of Business, Stanford University, USA, Ph.D. dissertation.

Fine, C.H., 1986. Quality improvement and learning in productive systems. Manag. Sci. 32 (10), 1301-1315.

Flynn, B.B., Flynn, J.E., Amundson, S.D., Schroeder., R.G., 1999. Product development speed and quality: A new set of synergies. In: Stahl, M.J. (Ed.), Perspectives in total quality. Boston. Blackwell Publishers, MA, pp. 245-271.

Flynn, B.B., Huo, B., Zhao, X., 2010. The impact of supply chain integration on performance: acontingency and configuration approach. J. Oper. Manag. 28 (1), $58-71$.

Flynn, B.B., Schroeder, R.G., Sakakibara., S., 1994. A framework for quality management research and an associated measurement instrument. J. Oper. Manag. $11,339-366$.

Flynn, B.B., Schroeder, R.G., Sakakibara., S., 1995a. Determinants of quality performance in high and-low quality plants. Qual. Manag. J. 2, 8-25.

Flynn, B.B., Schroeder, R.G., Sakakibara., S., 1995b. The impact of quality management practices on performance and competitive advantage. Decis. Sci. 26 (5), 659-691.

Fornell, C., Larcker., D.F., 1981. Evaluating structural equation models with unobservable variables and measurement error. J. Mark. Res. 18 (1), 39-50.

Frohlich, M., Westbrook., R., 2001. Arcs of integration: an international study of supply chain strategies. J. Oper. Manag. 19, 185-200.

Fynes, B., Voss, C., de Burca., S., 2005. The impact of supply chain relationship quality on quality performance. Int. J. Prod. Econ. 96, 339-354.

Gatignon, H., Xuereb., J.M.J., 1997. Strategic orientation of the firm and new product performance. J. Mark. Res. 34, 77-90.

Gefen, D., 2003. Unidimensional validity: an explanation and example. Commun. Assoc. Inf. Syst. 2 (12), 23-47.

Gerbing, D.W., Anderson., J.C., 1988. An updated paradigm for scale development incorporating unidimensionality and its assessment. J. Mark. Res. 25, 186-192.

Gibbons, R., Holden, R., Powell, M., 2010. Integration and information: firms' governance in rational expectations equilibrium. Working Paper.

Giffi, C., Roth, A.V., Seal., G.M., 1990. Competing in World Class Manufacturing: Americas 21st Century Challenge. Richard D. Irwin, Homewood, ILL.

Gimenez, C., Ventura., E., 2005. Logistics-production, logistics-marketing and external integration -their impact on performance. Int. J. Oper. Prod. Manag. 25 (1), 20-38.

Grant, R.M., 1996. Prospering in dynamically-competitive environments: organizational capability as knowledge integration. Organ. Sci. 7 (4), 375-387.

Griffin, A., 1997. The effect of project and process characteristics on produc development cycle time. J. Mark. Res. 34, 24-25.

Gunasekaran, A., Ngai., E.W.T., 2004. Information systems in supply chain integration and management. Eur. J. Oper. Res. 159, 269-295.

Hair, J.F., Anderson, R.E., Tatham, R.J., Black., W.C., 1995. Multivariate Data Analysis and Readings. Prentice Hall, Englewood Cliffs, NJ.

Hambrick, D.C., 1983. High profit strategies in mature capital goods industries: a contingency approach. Acad. Manag. J. 26 (4), 687-707.

Hammer, M., 2001. The superefficient company. Harv. Bus. Rev. 79, 82-91.

Harrigan, K.R., 1985. Strategies for Joint Ventures. Lexington Books, Lexington, MA.

Hayes, D.C., Hunton, J.E., Reck., J.L., 2001. Market reaction to ERP implementation announcements. Inf. Syst. 15 (1), 3-18.

Hendricks, K.B., Singhal, V.R., 2001. Firm characteristics, total quality management and financial performance. J. Oper. Manag. 19, 269-285.

Holweg, M., Pil., F.K., 2008. Perspectives on the coordination of supply chains. J. Oper. Manag. 26, 389-406.

Hoegl, M., Wagner., S.M., 2005. Buyer-supplier collaboration in product development projects. J. Manag. 31, 530-548.

Hopwood, A.G., 1996. Looking across rather than up and down: on the need to explore the lateral processing of information. Account. Organ. Soc. 21, 589-590.

Hsu, L.L., Chen, M., 2004. Impacts of ERP systems on the integrated-interaction performance of manufacturing and marketing. Ind. Manag. Data Syst. 104 (1), 42-55.

Hu, L.T., Bentler., P.M., 1999. Cutoff criteria for fit indexes in covariance structure analysis: Conventional criteria versus new alternatives. Struct. Equ. Model. 6, $1-55$.

Husted, B., Allen., D.B., 2006. Corporate social responsibility in the multinational enterprise: strategic and institutional approaches. J. Int. Bus. Stud. 37, 838-849.

Iansiti, M., Clark., K.B., 1994. Integration and dynamic capability: evidence from product development in automobiles and mainframe computers. Industrial and Corporate Change, 3. Oxford University Press, pp. 557-605.

Ittner, C.D., Larcker, D.F., 1996. Measuring the impact of quality initiatives on firm financial performance. In: Fedor, D.B., Ghosh, S. (Eds.), Advances in the Management of Organizational Quality: An Annual Series of Quality-Related Theory and Research Papers, Vol. 1 (no. 1). Jai Press, pp. 1-37.

Ittner, C.D., Lanen, W.N., Larcker., D.F., 2002. The association between activity-based costing and manufacturing performance. J. Account. Res. 40 (3), 711-726.

Jacobs, M., Vickery, S.K., Droge., C., 2007. The effects of product modularity on competitive performance. Do integration strategies mediate the relationship? Int. J. Oper. Prod. Manag. 27 (10), 1046-1068.

Juran, J.M., 1992. Juran on quality by design: the new steps for planning quality into goods and services. Free Press, New York. 
Kallunki, J.P., Laitinen, E.K., Silvola., H., 2011. Impact of enterprise resource planning systems on management control systems and firm performance. Int.l J. Account. Inf. Syst. 12, 20-39.

Kaplan, R.S., Cooper., R., 1998. Cost and Effect-using Integrated Cost Systems to Drive Profitability and Performance. Harvard Business School Press, Boston, MA

Kaynak, H., 2003. The relationship between total quality management practices and their effects on firm performance. Journal of Operations Management 21 (4), 405-435.

Kaynak, H., Hartley., J.L., 2008. A replication and extension of quality management into the supply chain. J. Oper. Manag. 26, 468-489.

Kim, S., Lee., H., 2010. Factors affecting employee knowledge acquisition and application capabilities. Asia-Pacific J. Bus. Adm. 2 (2), 133-152.

Kim, S.W., 2009. An investigation on the direct and indirect effect of supply chain integration on firm performance. Int. J. Prod. Econ. 19, 328-346.

Kinney, M.R., Wempe., W.F., 2002. Further evidence on the extent and origins of IIT's profitability effects. Account. Rev. 77 (1), 203-225.

Kotha, S., Vadlamani., B.L., 1995. Assessing generic strategies: an empirical investigation of two competing typologies in discrete manufacturing industries. Strateg. Manag. J. 16 (1), 75-83.

Koufteros, X.A., Marcoulides., G.A., 2006. Product development practices and performance: a structural equation modelling-based multi-group analysis. Int. J. Prod. Econ. 103 (1), 286-307.

Kroll, M., Wright, P., Heins., R.A., 1999. The contribution of product quality to competitive advantage: impacts on systematic variance and unexplained variance in returns. Strateg. Manag. J. 20 (1), 375-384.

Kulp, S., 2002. Effect of information precession and information reliability on manufacturer- retailer relationships. Account. Rev. 77, 653-677.

Kumar, V., 2014. Impact of information technology on supply chain of Indian industries. Int. J. Eng. 7 (1), 41-48.

Li, S., Rao, S.S., Ragu-Nathan, B., Ragu-Nathan., T.S., 2005. Development and validation of a measurement instrument for studying supply chain management practices. J. Oper. Manag. 23, 618-641.

MacKinnon, D.P., Lockwood, C.M., Williams., J., 2004. Confidence limits for the indirect effect: Distribution of the product and resampling methods. Multivar. Behav. Res. 39, 99-128.

Maiga, A.S., Nilsson., A., Jacobs., F.J., 2013. Extent of managerial IT use, learning routines, and firm performance: a structural equation modeling of their relationship. Int. J. Account. Inf. Syst. 14 (4), 297-320.

Menor, L.J., Roth, A.V., Mason., C.H., 2001. Agility in retail banking: a numerical taxonomy of strategic service groups. Manuf. Serv. Oper. Manag. 3 (4), 273-292.

Miller, D., 1987. The structural and environmental correlates of business strategy. Strateg. Manag. J.1 8 (1), 55-76.

Miller, D., Friesen., P.H., 1986. Porter's (1980) generic strategies and performance: an empirical examination with American data: Part 1-Testing Porter. Organ. Stud. 7 (1), 1-35

Narasimhan, R., Jayaram., J., 1998. Causal linkages in supply chain management: an exploratory study of North American manufacturing firms. Decis. Sci. 29 (3), 579-605.

Newbert, S.L., 2008. Value, rareness, competitive advantage, and performance: a conceptual-level empirical investigation of the resource-based view of the firm. Strateg. Manag. J. 29 (7), 745-768.

Noble, M.A., 1995. Manufacturing strategy: testing the cumulative model in a multiple country context. Decis. Sci. 26 (5), 693-721.

Olson, E.M., Walker Jr., O.C., Ruekert., R.W., 1995. Organizing for effective new product development: The moderating role of product innovativeness. J. Mark. 59 (1), 48-62.

Palaniswamy, R., Frank, T., 2000. Enhancing manufacturing performance with ERP systems. Inf. Syst. Manag. 17 (3), 43-55.

Pavlou H., 2004. IT-enabled dynamic capabilities in the new product development: Building a competitive advantage in the turbulent environments. Unpublished doctoral dissertation. University of Southern California.

Peteraf, M.A., 1993. The cornerstones of competitive advantage: a resource-based view. Strateg. Manag. J. 14 (3), 179-191.

Pijpers, G.G.M., Bemelmans, T., Heemstra, F.J., van Montfort., K.A.G.M., 2001. Senior executives' use of information technolo. Inf. Softw. Technol. 43 (5), 959-971.

Podsakoff, P.M.,S.B., MacKenzie, L.Y., Lee, N.P., 2003. J. Appl. Psychol. 88, 879-903.

Porter, M.E., 1980. Competitive strategy: techniques for analyzing industries and competitors. Free Press, New York, NY.

Porter, M.E., 1985. Competitive advantage: creating and sustaining superior performance. Free Press, New York, NY.

Poston, R., Grabski, S., 2001. Financial impacts of enterprise resource planning implementations. Int. J. Account. Inf. Syst. 2, 271-294.

Prajogo, D.I., Sohal., A.S., 2006. The relationship between organization strategy, total quality management (TQM) and organization performance-the mediating role of TQM. Eur. J. Oper. Res. 68, 35-50.

Prajogo, D.I., McDermott, P., Goh., M., 2008. Impact of value chain activities on quality and innovation. Int. J. Oper. Prod. Manag. 28 (7), 615-635.

Prajogo, D., Olhager., J., 2012. Supply chain integration and performance: the effects of long-term relationships, information technology and sharing, and logistics integration. Int. J. Prod. Econ. 135 (1), 514-522.

Preacher, K.J., Hayes, A.F., 2008. Contemporary approaches to assessing mediation in communication research. In: Hayes, A.F. Slater, M.D., Synder, L.B. (Eds.), The Sage Sourcebook of Advanced Data Analysis Methods for Communication Research. Sage Publications, Thousand Oaks, CA, pp. 13-54.

Rackoff, N.C., Wiseman, C., Ulrich., W., 1985. IS is for competitive advantage: implementation of a planning process. MIS Q. 9, 285-294.
Ragatz, G.L., Handfield, R.B., Petersen., K.J., 2002. Benefits associated with supplier integration into new product development under conditions of technology uncertainty. J. Bus. Res. 55 (5), 389-400.

Railing, L., Housel, T., 1990. A network infrastructure to contain costs and enable fast response: The TRW process. MIS 0. 14 (4), 405-419.

Raykov, T., 1997. Equivalent structural equation models and group equality constraints. Multivar. Behav. Res. 32, 95-104.

Raykov, T., Marcoulides., G.A., 2000. A First Course in Structural Equation Modeling. Lawrence Erlbaum, Mahwah, NJ.

Richardson, G., Jackson, B., Dickson., G., 1990. A principles-based enterprise architecture: lessons from Texaco and Star Enterprise. MIS Q. 14, 385-403.

Roth, A.V., Menor., L.J., 2003. Insights into service operations management: a research agenda. Prod. Oper. Manag. 12 (2), 145-164.

Rust, R.T., Moorman, C., Dickson., P.R., 2002. Getting return on quality: revenue expansion, cost reduction, or both? J. Mark. 66 (4), 7-24.

Sankar, M. Self-assessment using the Baldrige criteria Milwaukee, ASQC Professional and Technical Development 1995.

Santhanam, R., Hartono, E., 2003. Issues in linking information technology capability to firm performance. MIS Q. 27, 125-153.

Schlie, T.W., Goldhar., J.D., 1995. Advanced manufacturing and new directions for competitive strategy. J. Bus, Res. 33 (2), 103-114.

Shank, J.K., Govindarajan., V., 1993. Strategic cost management-the new tool for competitive advantage. The Free Press, New York, NY.

Shin, J., Sudhir, K., Yoon, D.-H., 2012. When to "fire" customers: customer costbased prici. Manag. Sci. 58 (5), 932-947.

Shrout, P.E., Bolger., N., 2002. Mediation in experimental and non-experimental studies: new procedures and recommendations. Psychol. Methods 7, 422-445.

Simoens, S., Scott., A., 2005. Integrated primary care organizations: to what extent is integration occurring and why? Health Serv. Manag. Res. 18, 25-40.

Singles, J., Ruel, G., van de Water, H., 2001. ISO 9000 series certification and performance. Int. J. Qual. Reliab. Manag. 18 (1), 62-75.

Sinkovics, R., Roath., A.S., 2004. Strategic orientation, capabilities, and performance in manufacturer - 3PL relationships. J. Bus. Logist. 25 (2), 43-64.

Slaughter, S.A., Harter, D.E., Krishnan., M.S., 1998. Evaluating the cost of software quality. Commun. ACM 41 (8), 67-73.

Song, X.M., Xie, J., Dyer., B., 2000. Antecedents and consequences of marketing managers' conflict-handling behavio. J. Market. 64, 50-66.

Spanos, Y.E., Zaralis, G., Lioukas., S., 2004. Strategy and industry effects on profitability: evidence from Greece. Strateg. Manag. J. 25 (2), 139-165.

Sriram, V., Stump., R., 2004. Information technology investments in purchasing: an empirical investigation of communications, relationships and performance outcomes. Omega- Int. J. Manag. Sci. 32 (2), 41-55.

Stratman, J.K., Roth., A.V., 2002. Enterprise resource planning (ERP) competence constructs: two-stage multi-item scale development and validation. Decis. Sci. 33 (4), 601.

Steiger, J. H., Lind, C. J., 1980. Statistically based tests for the number of factors. Paper Presented at the Meeting of the Psychometric Society, Iowa City, IA.

Stenzel, J., Stenzel., C., 2004. Performance measurement and management in the reinsurance industry. Cost Manag. 18 (3), 28-35.

Swafford, P.M., Ghosh, S., Murthy., N., 2008. Achieving supply chain agility through IT integration and flexibility. Int. J. Prod. Econ. 116 (2), 288-297.

Swink, M., Narasimhan, R., Wang., C., 2007. Managing beyond the factory walls: Effects of four types of strategic integration on manufacturing plant performance. J. Oper. Manag. 25 (1), 148-164.

Swink, M., Talluri, S., Pandejpong., T., 2006. Faster, better, cheaper: A study of NPD project efficiency and performance tradeoffs. J. Oper. Manag. 24 (6), 542-562.

Tan, K.C., 2001. A structural equation model of new product design and development. Decis. Sci. 32 (2), 195-226.

Tatikonda, M.V., Montoya-Weiss., M.M., 2001. Integrating operations and marketing perspectives of product innovation: the influence of organizational process factors and capabilities on development performance. Manag. Sci. 47 (1), $151-172$.

Tchokogue, A., Bareil, C., Duguay., C.R., 2005. Key Lessons from the Implementation of an ERP at Pratt \& Whitney Canada. Int. J. Prod. Econ. 95 (2), 151-163.

Teece, D.J., Pisano, G., Shuen., A., 1997. Dynamic capabilities and strategic management. Strateg. Manag. J.l 18 (7), 509-533.

Tsekouras, K., Dimara, E., Skuras., D., 2002. Adoption of a quality assurance scheme and its effect upon firm performance: a study of Greek firms implementing BS EN ISO 9000:2000. Total Qual. Manag. 13 (6), 827-841.

Verona, G., 1999. A resource-based view of product development. Acad. Manag. Rev. 24 (1), 132-142.

Vickery, S.K., Jayaram, J., Droge, C., Calantone., R., 2003. The effects of an integrative supply chain strategy on customer service and financial performance: an analysis of direct versus indirect relationships. J. Oper. Manag. 21 (5), 523-539.

Voss, C., K. Blackmon., 1994. Total quality management and ISO 9000: an European study. London, Centre for Operations Management, London Business School. Working Paper.

Wade, M., Hulland., J., 2004. Review: The resource-based view and information systems research: review, extension, and suggestions for future research. MIS Q. 28 (1), 107-142.

Ward, P., Zhou, H., 2006. Impact of information technology integration and lean/ iust-in-time practices on lead-time performance. Decis. Sci. 37, 177-203.

Wayhan, V.B., Kirche, E.T., Khumawala., B.M., 2002. ISO 9000 certification: the financial performance implications. Total Qual. Manag. 13 (2), 217-231. 
Weiner, B.J., Savitz, L.A., Bernard, S., Pucci., L.G., 2004. How do integrated delivery systems adopt and implement clinical information systems. Healthc. Manag. Rev. 29 (1), 51-66.

Wilkin, C.L., Chenhall, R.H., 2010. A review of IT governance: a taxonomy to inform accounting information systems. J. Inf. Syst. 24 (2), 107-146.

Wong, C.Y., El-Beheiry, M.M., Johansen, J., Hvolby., H.H., 2007. The implications of information sharing on bullwip effects in a toy supply chain. Int. J. Risk Assess. Manag. 7 (1), 4-18.

Wong, C.Y., Boon-itt, S., Wong., C.W.Y., 2011. The contingency effects of environmental uncertainty on the relationship between supply chain integration and operational performance. J. Oper. Manag.t 29, 604-615.

Wu, H., Lin, B., Chen, C., 2007. Contingency view on technological differentiation and firm performance: Evidence in an economic downturn. Rand Manag. 37 (1), 75-88.

Wu, K., Nagurney, A., Liu, Z., Strandlund., J.K., 2006. Modeling generator power plant portfolios and pollution taxes in electric power supply chain networks: a transportation network equilibrium transformation. Transp. Res. Part D 11 (3), 171-190.

Xiao, L., 2008. The impact of dynamic IT capability and organizational culture on firm performance. Unpublished dissertation. The George Washington University.

Yusuf, Y.Y., Gunasekaran, A., Adeleye, E.O., Sivayoganathan., K., 2004. Agile supply chain capabilities: determinants of competitive objectives. Eur. J. Oper. Res. 159 (2), 379-392.

Zhou, H., Benton., W.C., 2007. Supply chain practice and information sharing. J. Oper. Manag. 25 (6), 1348-1365.

Zsidisin, G.A., Smith., M.E., 2005. Managing supply risk with early supplier involvement: a case study and research propositions. J. Supply Chain Manag. 41, 44-57. 